\title{
The impact of intergenerational programs on social capital in Japan: a randomized population-based cross-sectional study
}

\author{
Yoh Murayama $^{1 *}$, Hiroshi Murayama ${ }^{2}$, Masami Hasebe ${ }^{3}$, Jun Yamaguchi ${ }^{1}$ and Yoshinori Fujiwara ${ }^{1}$
}

\begin{abstract}
Background: Over the last several decades, social isolation and loneliness among older adults have posed an increasingly urgent challenge due to the rapidly aging population in Japan. To remedy the situation, many communities have introduced intergenerational programs. However, few studies have investigated the benefits of social capital across generations as a result of intergenerational interaction between children and older generations. Therefore, we aim to ascertain the degree to which intergenerational programs that take root in a community will affect the social capital of all generations in the community.

Methods: We focus our research on one specific program, REPRINTS, an intergenerational health promotion program for older adults that has been active for over 10 years in Tama Ward, Kawasaki City, Kanagawa Prefecture. We conducted a population-based cross-sectional study of residents between the ages of 20 and 84 years who were randomly selected from the basic resident register. Approximately 2500 residents were selected, of which 978 responded; data from 891 respondents were analyzed.

Results: Hierarchical linear modeling suggests that the duration of programs was a significant community-level indicator of neighborhood trust. At the individual level, people between 30 and 59 years of age and people over 60 years of age have more positive effects on neighborhood trust than do people between 20 and 39 years of age.

Conclusions: The ongoing intergenerational programs between older citizens and children can enforce neighborhood trust, thus strengthening a community's intergenerational ties. The REPRINTS program has been developed through cooperation with local citizens, senior volunteers, and teachers from the community. Its collaborative nature ensures longevity and continuous growth in a community. It is challenging to create long-term intergenerational programs that take root in communities, making persistence and collaboration a crucial factor in fruitful intergenerational relationships. Overall, ongoing intergenerational program implementation associates with building social capital, thereby strengthening potential intergenerational ties and promote mutual support among local residents which will reduce or prevent social isolation among older.
\end{abstract}

Keywords: Intergenerational program, Social capital, Senior volunteer aging

\footnotetext{
* Correspondence: yhoyho05@tmig.or.jp

${ }^{1}$ Research Team for Social Participation and Community Health, Tokyo

Metropolitan Institute of Gerontology, 35-2 Sakae-cho, Itabashi-ku, Tokyo

178-0015, Japan

Full list of author information is available at the end of the article
}

(c) The Author(s). 2019 Open Access This article is distributed under the terms of the Creative Commons Attribution 4.0 International License (http://creativecommons.org/licenses/by/4.0/), which permits unrestricted use, distribution, and reproduction in any medium, provided you give appropriate credit to the original author(s) and the source, provide a link to the Creative Commons license, and indicate if changes were made. The Creative Commons Public Domain Dedication waiver (http://creativecommons.org/publicdomain/zero/1.0/) applies to the data made available in this article, unless otherwise stated. 


\section{Background}

Over the past few decades, the population of several developed countries, including Japan, has begun to age rapidly. At the same time, studies show that the number of older people who live alone is increasing and that older citizens are more socially isolated than they have ever been $[1,2]$. Other research suggests that social isolation and loneliness have negative effects on physical and mental health [3]. As a result of these findings, increasing attention is being placed on helping older people maintain interpersonal relationships. One possible way to build interpersonal relations is to develop greater social capital within local communities [4]. Social capital is defined as social networks that share norms, values, and understandings, facilitating cooperation within or among group $[5,6]$. Previous studies have shown that social capital has a positive effect on several health outcomes, including mortality, hospitalization, self-rated health, and depression [7-9].

To network local residents and reconstruct communities, many local communities have implemented intergenerational programs [10-15]. An intergenerational program is a social service that involves the ongoing and purposeful exchange of resources between members of younger and older generations [16, 17]. Intergenerational programs were started in the United States to address emerging social problems, including improving educational success for young people, reducing ageism, and increasing the quality of life for older citizens [18-21]. For example, Experience $\mathrm{Corps}^{\circ}$ is an intergenerational program that began in the United States in 1996. It trains senior volunteers to work in schools to improve students' academic outcomes, and Experience Corps ${ }^{\oplus}$ volunteers assist teachers with literacy and library work [22].

Previous studies have shown that intergenerational programs have positive influences on several outcomes. Older adults benefit from improved physical and mental health, and increased social activities [10, 22-29]. School children will benefit from these programs through improved academic performance, positive perception of the elderly, and attitudes toward community activities [30-32]. Moreover, intergenerational programs would develop social relationships across generations through cooperation with local coordinators, senior volunteers, and teachers from the community. This would further strengthen potential intergenerational ties and promote mutual supports among local residents [25, 33].

While these studies have focused on understanding the individual benefits of intergenerational programs, few studies have investigated the effects on social capital. One exception is the work of Bostrom [33], who conducted a questionnaire-based survey among participants in the "Class Granddad" program run in a limited number of Stockholm schools. Demonstrating that the program has an effect on pupils' cognitive social capitalthat is, the individual's subjective perception of social resources -Bostrom [33] indicates that the social capital benefits of intergenerational programs spill over to other generations as a result of intergenerational interaction (Fig. 1). Figure 1 illustrates the relationship between social capital in the community and health promotion intervention programs, proposing that enhanced social capital can positively influence the continuation and impact of such programs. In other words, this model indicates that the social capital benefits of one generation spill over to other generations over time. Similarly, Bekkers et al. [34] have suggested that the intensity and duration of contact can promote the trust. This suggests that ongoing intergenerational programs increase the social capital of not only the target age group but all the generations in a community. However, few studies have investigated the effects of spillover on social capital in local communities. In order to verify the effects of spillover on social capital, we aim to investigate the association between the degree to which intergenerational programs take root in the community and social capital among local residents. We then focus on the REPRINTS program, an intergenerational program training senior volunteers to work in schools.

The "Research of Productivity by Intergenerational Sympathy," or REPRINTS, program in Japan, trains volunteers over the age of 60 to read picture books to school children [35]. The program started in three areas: Chuo Ward, central Tokyo; Tama Ward, Kawasaki City, Kanagawa Prefecture, a suburb of Tokyo; and Nagahama City, Shiga Prefecture, a rural area in western Japan. REPRINTS participants were recruited from March to July 2004 through community newspapers, newsletters, and events advertising the program. After submitting a volunteer application, applicants attended intensive weekly training seminars for three months where they underwent projects involving picture book reading. Thereafter, they began reading picture books in elementary schools, kindergartens, and public childcare centers. Volunteers were asked to participate once every one to two weeks in groups of about six to ten members. By 2016, the number of locations had increased to eight and the number of senior volunteers had reached about 300 people [36].

Thus, we hypothesized that the degree to which REPRINTS programs take root in a community will affect the social capital of all generations in the community.

\section{Methods}

\section{Participants}

We focused our research on the REPRINTS program in Tama Ward, Kawasaki City, which has a total population 


\section{Persistent impact \\ on health

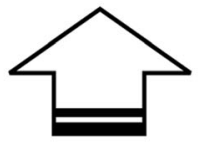

Established health promotion activities

Step 2
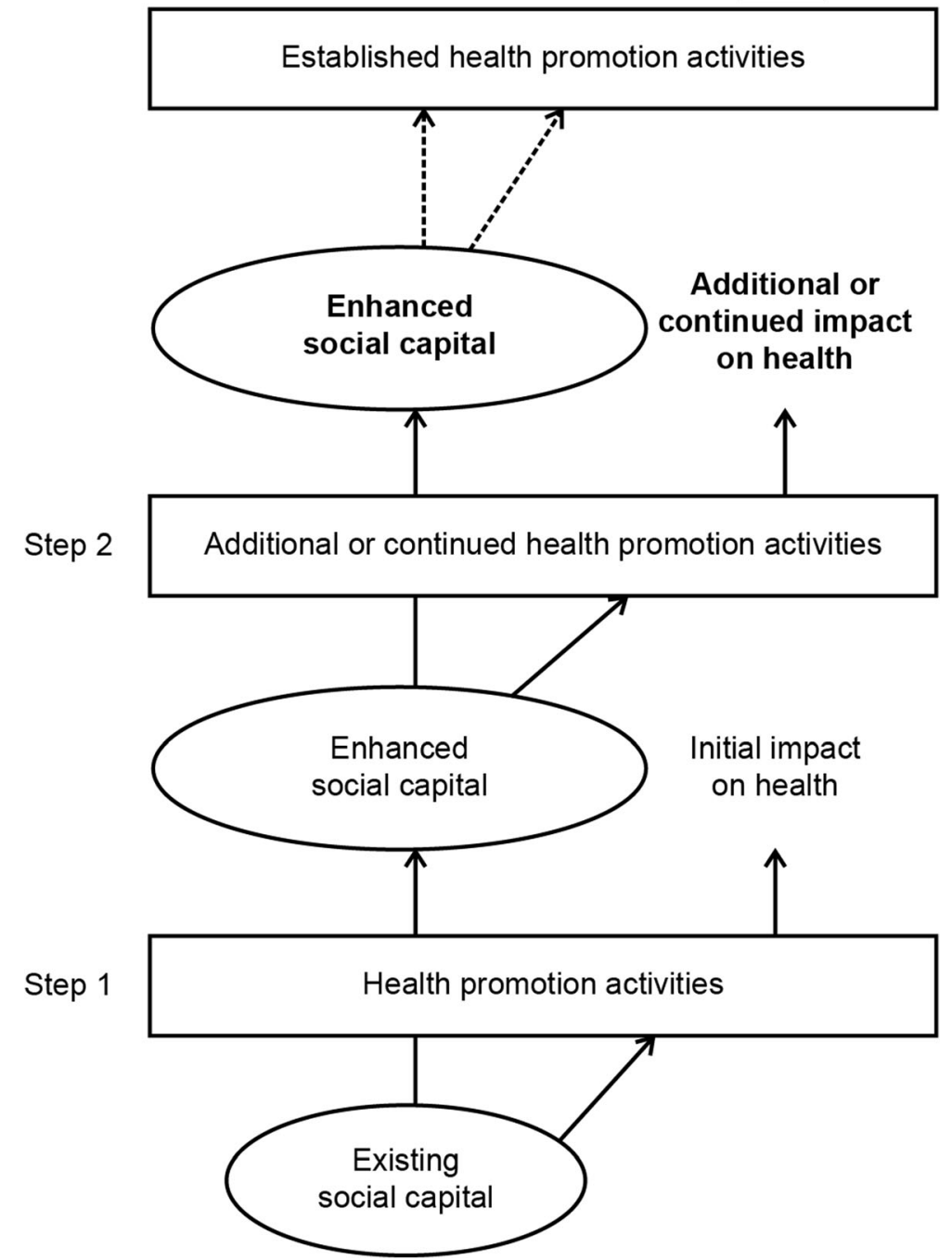

Fig. 1 Illustration of the desired relationship between social capital and health promotion intervention programs [12]

of 214,158 residents (about 104,099 of which are female) as of October 2015 [37]. The program had been around for approximately ten years at the time of our research. In 2016, 65 senior volunteers in Tama participated in about 30 institutions, including schools, kindergartens, and public childcare centers.

We conducted a survey among local residents, randomly selecting 2500 (of 171,167) respondents between the ages of 20 and 84 from the basic resident register system - the official Japanese system of recording residents - in Tama ward, using a stratified random sampling method by age and gender. The selected residents received the questionnaire in March 2015, and 978 residents (461 male and 517 female) responded, resulting in a response rate of $39.1 \%$. Response rates varied across the districts: $\mathrm{SD}=5.75$; Range, 28.3-50.5\%. We excluded responses from respondents with missing values for key variables. After eliminating all missing data, we analyzed the data of 891 residents in total.

\section{Outcome measures}

We asked respondents for the following demographic information: age in years, gender, highest school grade achieved, living arrangement, duration of residence, and perceived financial status. 
We assessed social capital through two question items, both used in previous studies on social capital [38-41]. First, we asked respondents to rate whether they trusted their neighborhood (neighborhood trust, "people in this neighborhood can be trusted") using a 5-point Likert scale from 1 (agree) to 5 (disagree). Second, we asked respondents whether they want to be helpful in their neighborhood (neighborhood norms, "people in the neighborhood are willing to help one another") using a 5-point Likert scale ranging from 1 (agree) to 5 (disagree).

We measured the degree to which the REPRINTS programs take root in the community by the program's duration; how long the program had been around, number of activities, and recognition of the program. Some of this information was obtained from program staff. Table 1 shows that REPRINTS spread gradually throughout Tama over a period of 11 years. By the time of our study, it was active in 13 of 24 districts (Duration of program: Mean $=1.37, S D=1.09$, Number of programs: Mean $=1.05, S D=0.97$ ). There was no difference in response rate between REPRINTS program intervention districts and non-intervention districts: $t(22)=0.71, p=0.48$ ).

We categorized the duration of REPRINTS programs by breaking them into four categories based on when they began: Term 1 (2004-2005), Term 2 (2006-2010), Term 3 (2011-2015), and districts with no intervention programs. We then quantified the number of activities as the number of types of institutions in each district where senior volunteers participated: Type 1 (one institution: kindergarten, elementary school, junior high school, etc.), Type 2 (two institutions), Type 3 (three institutions), and districts with no REPRINTS intervention. Finally, we assessed the recognition of REPRINTS through the question, "Do you know whether the REPRINTS, senior volunteers for picture book reading to children, has worked in Tama Ward?" answered according to a 3-point Likert scale ranging from 1 ("I don't know about them at all") to 3 ("I know about REPRINTS"). We then asked the respondents who claimed to know about REPRINTS whether they, their family members, or acquaintances have been participated in the REPRINTS program.

Table 1 REPRINTS' degree of penetration in Tama Ward districts

\begin{tabular}{lllll}
\hline Duration & 2004-2005 & 2006-2010 & 2011-2015 & No intervention \\
& (Term 1) & $($ Term 2) & (Term 3) & \\
& 3 & 7 & 3 & 11 \\
Number & One place & Two places & Three places & No intervention \\
& (Type 1) & (Type 2) & (Type 3) & \\
9 & 2 & 2 & 11 \\
\hline
\end{tabular}

Note. The numbers in the table represent the number of Tama ward districts

\section{Data analysis}

Our descriptive data analysis used chi-square tests or a one-way ANOVA test to compare demographics and basic variables among age groups in IBM SPSS version 20.0. As local residents are nested within local communities, we examined relationships across these levels using hierarchical linear modeling in HLM 7.02, with neighborhood trust and neighborhood norms as the outcome [42]. We constructed three models and used deviance as a global adjustment measure. The first model (Model 1) was examined to calculate the intraclass correlation coefficient in order to estimate how much of the total variance in neighborhood trust or neighborhood norm was associated with community context. In Model 2, the individual-level variables (e.g., gender, recognition of intergenerational programs, duration of residence, and perceived financial status) were inserted. Model 3 added the community-level variables, including the duration and number of intergenerational programs.

\section{Results}

Table 2 shows the demographic results of our survey. The mean age was 49.5 (range: 20-83). The sample was predominantly comprised of females $(53.0 \%)$ with at least a high school education (66.8\%). The majority of the participants lived with others $(85.2 \%)$, while $13.3 \%$ lived alone. According to the 2015 population census, $34.6 \%$ of the general population lived alone in 2015 [43], indicating that the ratio of our sample is higher than that of the general population. We also found a statistically significant difference in the duration of residence and the perceived financial status among different age groups. Residual analysis showed that people over the age of 60 lived in their communities longer than people in their $20 \mathrm{~s}$ and $30 \mathrm{~s}$. There were significant differences in the scores for neighborhood norms and neighborhood trust among different age groups. Bonferroni's multiple comparison tests showed that the scores for people over the age of 60 and between the ages of 40 and 59 were significantly higher than that for people between the ages of 20 and 39 years. There were no differences between the age groups with regard to the recognition of the program. Although there were no REPRINTS participants among respondents, eight respondents claimed that family members or acquaintances participated in REPRINTS programs.

Tables 3 and 4 show the relationship between the degree to which the REPRINTS programs take root in a community, neighborhood trust, and neighborhood norm for each age category. With regard to neighborhood trust, the duration of programs was a significant community-level indicator of neighborhood trust. At the individual level, the duration of residence and living alone was negatively 
Table 2 Demographic results

\begin{tabular}{|c|c|c|c|c|c|}
\hline \multirow[t]{2}{*}{ Individual characteristics } & All & $20-39$ years $(n=285)$ & $40-59$ years $(n=316)$ & $60+$ years $(n=290)$ & \multirow[t]{2}{*}{$p$-value } \\
\hline & $n(\%)$ or M (SD) & $n(\%)$ or M (SD) & $n(\%)$ or M (SD) & $n(\%)$ or M (SD) & \\
\hline \multicolumn{6}{|l|}{ Gender } \\
\hline Male & $419(47.0)$ & $135(47.4)$ & $146(46.2)$ & $138(47.6)$ & \multirow[t]{2}{*}{0.934} \\
\hline Female & $472(53.0)$ & $150(52.6)$ & $170(53.8)$ & $152(52.4)$ & \\
\hline \multicolumn{6}{|l|}{ Education } \\
\hline Less than high school & $58(6.5)$ & $2(0.7)$ & $11(3.5)$ & $45(15.5)$ & \multirow[t]{3}{*}{0.001} \\
\hline High school degree & $238(26.7)$ & $59(20.7)$ & $71(22.5)$ & $108(37.2)$ & \\
\hline More than high school & $595(66.8)$ & $224(78.6)$ & $234(74.1)$ & $138(47.6)$ & \\
\hline \multicolumn{6}{|l|}{ Living arrangement } \\
\hline Lives alone & $119(13.3)$ & $43(15.2)$ & $35(11.1)$ & $41(14.7)$ & \multirow[t]{3}{*}{0.270} \\
\hline Lives with others & $763(85.2)$ & $240(84.8)$ & $281(88.9)$ & $238(85.3)$ & \\
\hline No Answer & $14(1.6)$ & $2(0.7)$ & $0(0.0)$ & $11(3.8)$ & \\
\hline \multicolumn{6}{|l|}{ Duration of residence } \\
\hline Over ten years & $509(57.1)$ & $211(26.0)$ & $136(57.0)$ & $35(87.9)$ & 0.001 \\
\hline \multicolumn{6}{|l|}{ Perceived financial status } \\
\hline Slightly or Extremely & $331(37.1)$ & $119(42.8)$ & $103(32.6)$ & 109 (37.6) & 0.067 \\
\hline \multicolumn{6}{|l|}{ Sufficient Social capital } \\
\hline Neighborhood trust & $3.29(0.91)$ & $3.09(0.97)$ & $3.29(0.86)$ & $3.47(0.86)$ & 0.001 \\
\hline Neighborhood norm & $3.21(0.89)$ & $3.06(0.88)$ & $3.26(0.87)$ & $3.31(0.90)$ & 0.002 \\
\hline Recognition of program & $1.19(0.51)$ & $1.14(0.49)$ & $1.22(0.54)$ & $1.19(0.48)$ & 0.191 \\
\hline
\end{tabular}

Notes: $p$ values obtained using chi-square test or one-way ANOVA test

Table 3 Multilevel models predicting neighborhood trust

\begin{tabular}{|c|c|c|c|c|c|c|c|c|c|}
\hline & \multicolumn{3}{|l|}{ Model 1} & \multicolumn{3}{|l|}{ Model 2} & \multicolumn{3}{|l|}{ Model 3} \\
\hline & Coeff. & SE & $p$-value & Coeff. & SE & $p$-value & Coeff. & SE & $p$-value \\
\hline \multicolumn{10}{|l|}{ Individual-level variables } \\
\hline Intercept & 3.280 & 0.032 & $<0.001$ & 2.763 & 0.188 & $<0.001$ & 2.276 & 0.428 & $<0.001$ \\
\hline Gender & & & & 0.001 & 0.064 & 0.982 & 0.007 & 0.064 & 0.917 \\
\hline \multicolumn{10}{|l|}{ Age (ref $=20-39$ years $)$} \\
\hline 30-59 years & & & & 0.156 & 0.080 & 0.052 & 0.157 & 0.080 & 0.049 \\
\hline $60+$ years & & & & 0.337 & 0.086 & $<0.001$ & 0.340 & 0.086 & $<0.001$ \\
\hline Education & & & & 0.134 & 0.070 & 0.056 & 0.132 & 0.070 & 0.059 \\
\hline Duration of residence & & & & -0.149 & 0.049 & 0.002 & -0.135 & 0.048 & 0.005 \\
\hline Living alone & & & & -0.276 & 0.073 & $<0.001$ & -0.274 & 0.071 & $<0.001$ \\
\hline Perceived financial status & & & & 0.215 & 0.064 & $<0.001$ & 0.214 & 0.064 & $<0.001$ \\
\hline Recognition of programs & & & & 0.126 & 0.055 & 0.023 & 0.113 & 0.054 & 0.038 \\
\hline \multicolumn{10}{|l|}{ Community-level variables } \\
\hline Duration of programs & & & & & & & 0.045 & 0.017 & 0.019 \\
\hline Number of programs & & & & & & & -0.007 & 0.033 & 0.837 \\
\hline Recognition of program & (mean) & & & & & & 0.367 & 0.374 & 0.339 \\
\hline Random Effect & Variance Component & $x^{2}$ & $p$-value & Variance Component & $x^{2}$ & $p$-value & Variance Component & $x^{2}$ & $p$-value \\
\hline Intercept & 0.0026 & 22.955 & $>0.500$ & 0.0010 & 20.517 & $>0.500$ & 0.0003 & 16.948 & $>0.500$ \\
\hline
\end{tabular}


Table 4 Multilevel models predicting neighborhood norm

\begin{tabular}{|c|c|c|c|c|c|c|c|c|c|}
\hline & \multicolumn{3}{|l|}{ Model 1} & \multicolumn{3}{|l|}{ Model 2} & \multicolumn{3}{|l|}{ Model 3} \\
\hline & Coeff. & SE & $p$-value & Coeff. & SE & $p$-value & Coeff. & SE & $p$-value \\
\hline \multicolumn{10}{|l|}{ Individual-level variables } \\
\hline Intercept & 3.203 & 0.030 & $<0.001$ & 2.704 & 0.163 & $<0.001$ & 1.875 & 0.389 & $<0.001$ \\
\hline Gender & & & & -0.004 & 0.056 & 0.940 & -0.001 & 0.057 & 0.998 \\
\hline \multicolumn{10}{|l|}{ Age (ref $=20-39$ years) } \\
\hline 40-59 years & & & & 0.187 & 0.084 & 0.027 & 0.191 & 0.084 & 0.023 \\
\hline $60+$ years & & & & 0.264 & 0.085 & 0.002 & 0.267 & 0.086 & 0.002 \\
\hline Education & & & & 0.135 & 0.066 & 0.042 & 0.148 & 0.066 & 0.026 \\
\hline Duration of residence & & & & -0.041 & 0.056 & 0.467 & -0.035 & 0.055 & 0.521 \\
\hline Living alone & & & & -0.216 & 0.086 & 0.012 & -0.207 & 0.086 & 0.016 \\
\hline Perceived financial status & & & & 0.114 & 0.072 & 0.113 & 0.117 & 0.071 & 0.099 \\
\hline Recognition of programs & & & & 0.112 & 0.046 & 0.015 & 0.089 & 0.047 & 0.058 \\
\hline \multicolumn{10}{|l|}{ Community-level variables } \\
\hline Duration of programs & & & & & & & -0.006 & 0.021 & 0.780 \\
\hline Number of programs & & & & & & & 0.015 & 0.027 & 0.583 \\
\hline Recognition of program & (mean) & & & & & & 0.683 & 0.336 & 0.056 \\
\hline Random Effect & Variance Component & $x^{2}$ & $p$-value & Variance Component & $x^{2}$ & $p$-value & Variance Component & $x^{2}$ & $p$-value \\
\hline Intercept & 0.0008 & 25.548 & 0.322 & 0.0004 & 24.698 & 0.366 & 0.0002 & 19.527 & $>0.500$ \\
\hline
\end{tabular}

SE Standard error, Coeff Coefficient, Ref Reference

associated with neighborhood trust, while perceived financial status and recognition of program was positively associated with neighborhood trust. Furthermore, people between the ages of 30 and 59 and those over the age of 60 were more positively associated with neighborhood trust than people between the ages of 20 and 39. The fit of model 3 proved better than that of the previous model.

As for the neighborhood norm, none of the community-level indicators proved to be statistically significant. At the individual level, living alone was negatively associated with neighborhood norm, while education was positively associated with neighborhood norm. More specifically, people between the ages of 30 and 59 and people over 60 were more positively associated with neighborhood norm than those between the ages of 20 and 39. The fit of model 3 proved better than that of the previous model.

\section{Discussion}

This study investigates the relationship between the degree to which REPRINTS take root in the community and social capital. Our results show that not only the recognition of the REPRINTS program but also the duration of the intergenerational program is related to neighborhood trust. More specifically, people over the age of 60 and between the ages of 40 and 59 are more likely to have a positive influence on neighborhood trust than those between the ages of 20 and 39 years.
According to a national survey in Japan, older people tend to have stronger neighborhood ties than young people [44]. In addition, middle-aged people often benefit from intergenerational programs, since these programs may provide childcare or other support services. Fujiwara et al. have examined how the parents of school children participating in REPRINTS, the Japanese program studied in this paper, have a more favorable evaluation of the program after two years [45]. They conclude that REPRINTS can help establish trust between older people and the parents of school children. In contrast, younger generations are often less tied to local communities. They often move from one community to another to attend the best schools, find a job, and get married. Indeed, a 2015 demographic survey of Kawasaki found that among people in Tama Ward, those in their 20s and 30s were the most likely to move from Tama Ward to another place [46]. This study's findings reflect the fact that older and middle-aged people tend to stay in residence longer than the younger generation. Taking all of these findings into account indicates that middle-aged and older residents are more likely to have contacts with or benefit from REPRINTS than members of the younger generation, who are newer to the area. Thus, REPRINTS seems to enhance the neighborhood trust among older and middle-aged people who have stronger neighborhood ties in a community.

Intergenerational programs like REPRINTS can be understood as bridging the social capital or social ties of 
heterogeneous groups. Polson et al. [47] suggest that bridging social capital is valuable to communities, since it connects individuals and leaders, inspiring them to work together for their community. To form these social networks, we assume that trust is the most important factor for social capital, since it is based on intimate familiarity with others [48]. Therefore, networking among local residents through the REPRINTS program should promote neighborhood trust. REPRINTS started several years ago in Tama Ward in Kawasaki City, and has become a well-established childcare policy over the past ten years. Murayama et al. [30] show that REPRINTS' intergenerational exchange between senior volunteers and elementary school students positively affects students' attitudes toward the community when they reach junior high. This finding suggests that ongoing REPRINTS programming enhances neighborhood trust among middle-aged and older local residents.

Our results support the theory that these intervention programs, while only involving senior citizens and young children, often have a spillover effect on other generations [12]. This suggests that intervention programs enhance social capital in two ways: they benefit children and senior citizens through the interventions themselves, and the community benefits through the presence of a long-term REPRINTS program.

Kaplan [49] argues that intergenerational programs providing intensive contact between generations and ongoing opportunities for intimate intergenerational engagement provide a valuable framework with which to conceptualize, categorize, and understand the impact of intergenerational programs. Other recent studies have focused on a "circle of care," or a circle of continued intergenerational reciprocity [50-53]. According to this concept, a sustainable community relies on reciprocal relations among local residents of all generations, which may be achieved through continuous and intimate intergenerational exchanges. However, there is little evidence that the "circle of care" occurred among REPRINTS participants in this study. Therefore, a qualitative study of participants is necessary to help determine this.

The REPRINTS program was developed through cooperation with local coordinators, senior volunteers, administrative officers, and local teachers. Its collaborative nature ensures its longevity and enables it to create neighborhood trust among local residents of many generations. As such, it creates the best possible environment for positive and long-lasting benefits, enforcing social capital and building sustainable community which will reduce or prevent social isolation among older. However, programs like REPRINTS are rare, especially in Japan, where few intergenerational programs are ongoing [54]. Therefore, it is a challenge to create and implement long-term intergenerational programs that take root in local communities and boost social capital.

\section{Study limitations}

While our study offers evidence for the relationship between social capital and the penetration of intergenerational programs, there are some limitations. First, our sample only includes active and relatively healthy adults living in a specific area. To address this concern, future studies must recruit people from varying socioeconomic conditions in a number of different communities using a random sampling technique. Second, there is a limitation in assessing neighborhood social capital with just two questions. In future research, neighborhood social capital should be evaluated using multiple standardized social capital scales. Third, this study did not consider numerous other factors that may also play a role in enhancing social capital in a community such as economy, crime rate, neighborhood beauty, cost of living, and civic engagement. Future analyses should control for these predictors. Fourth, with respect to data analysis, the results were correlational in nature; therefore, we cannot infer causality between the variables. Future studies should be conducted using panel surveys. Finally, we suggest examining differences across communities as the logical next step in this avenue of research.

\section{Conclusions}

Overall, the findings of this study suggest that ongoing intergenerational programs between older citizens and children can reinforce neighborhood trust among local residents, thereby strengthening a community's intergenerational ties. Moreover, this study indicates that program duration may reflect levels of community social capital. Future research is needed to show the causality between ongoing intergenerational programs and neighborhood trust, clarifying the factors that promote and inhibit the development of reciprocal relations among local residents.

\section{Acknowledgements \\ Not applicable.}

\section{Funding}

This work was supported by JSPS KAKENHI (Grant Number 26285143). The funding body had no role in the design of the study; the collection, analysis, and interpretation of data; or in the writing of the manuscript.

\section{Availability of data and materials}

The datasets used and/or analyzed during the current study are available from the corresponding author on reasonable request.

\section{Authors' contributions}

YM contributed to the design, implementation, data-collection, data-analyses, and writing of the manuscript. HM coordinated statistical analyses and contributed to critically refining the article. $\mathrm{MH}$ and JY were involved in conducting the study. YF was project leader. All authors read and approved the final manuscript. 


\section{Ethics approval and consent to participate}

- All participants were informed of their right to withdraw from the study at any time, and written consent was obtained from all participants.

- The Research Ethics Committee at the Tokyo Metropolitan Institute of Gerontology approved the study (Approval number 2023; approved on Dec 15, 2014).

\section{Consent for publication}

Consent for publication is not applicable because no individual patient data in any form have been reported in this article.

\section{Competing interests}

The authors declare that they have no competing interests.

\section{Publisher's Note}

Springer Nature remains neutral with regard to jurisdictional claims in published maps and institutional affiliations.

\section{Author details}

${ }^{1}$ Research Team for Social Participation and Community Health, Tokyo Metropolitan Institute of Gerontology, 35-2 Sakae-cho, Itabashi-ku, Tokyo 178-0015, Japan. ${ }^{2}$ Institute of Gerontology, The University of Tokyo, Tokyo, Japan. ${ }^{3}$ Department of Human Welfare, Seigakuin University, Saitama, Japan.

Received: 3 July 2018 Accepted: 25 January 2019

Published online: 06 February 2019

\section{References}

1. Cabinet Office Japan. Annual Report on the Aging Society 2017. 2017. https://www8.cao.go.jp/kourei/whitepaper/w-2017/html/zenbun/index.html. Accessed 29 Aug 2017

2. Landeiro F, Barrows P, Musson EN, Gray AM, Leal J. Reducing social isolation and loneliness in older people: a systematic review protocol. BMJ Open. 2017;7:e013778.

3. Nicholson NR. A review of social isolation: an important but underassessed condition in older adults. J Prim Prev. 2012;33:137-52.

4. Grootaert C, van Bastelaer T. Understanding and measuring social capital: A synthesis of findings and recommendations from the social capital initiative. The World Bank, Social Capital Initiative, Working paper no. 24. 2001. http://siteresources.worldbank.org/INTSOCIALCAPITAL/Resources/ Social-Capital-Initiative-Working-Paper-Series/SCI-WPS-24.pdf\#search= 'UNDERSTANDING+AND+MEASURING+SOCIAL+CAPITAL\%3A'. Accessed 31 Oct 2018.

5. Organization for Economic Co-operation and Development. The well-being of nations: The role of human and social capital. Paris: OECD; 2001.

6. Putnam RD. Bowling alone: the collapse and revival of American community. New York: Simon \& Schuster; 2000.

7. De Silva MJ, McKenzie K, Harpham T, Huttly SR. Social capital and mental illness: a systematic review. J Epidemiol Community Health. 2005;59:619-27.

8. Gilbert KL, Quinn SC, Goodman RM, Butler J, Wallace J. A meta-analysis of social capital and health: a case for needed research. J Health Psychol. 2013; 18:1385-99.

9. Kondo N, Sembajwe G, Kawachi I, van Dam RM, Subramanian SV, Yamagata Z. Income inequality, mortality, and self-rated health: meta-analysis of multilevel studies. BMJ. 2009;339:b4471.

10. Glass TA, Freedman M, Carlson MC, Hill J, Frick KD, lalongo N, et al. Experience corps: design of an intergenerational program to boost social capital and promote the health of an aging society. J Urban Health. 2004; 81:94-105.

11. Murayama Y. Adult generativity for the socialization of children: exchanges between aged persons and children in Japanese local communities. J Polit Sci Soc. 2010;12:85-102

12. Murayama H, Fujiwara Y, Kawachi I. Social capital and health: A review of prospective multilevel studies. J Epidemiol. 2012;22:179-87.

13. Pain R. Intergenerational relations and practice in the development of sustainable communities. London: ODPM; 2005.

14. Raynes NV, Rawlings BR. Recreating social capital: intergenerational programmes and bridging networks: an English model-phase 1. J Intergener Relatsh. 2004;2:7-28.
15. Yarrow AL. Sustainability and intergenerational solidarity. Generations. 2009; 33:103-4.

16. Kaplan M, Henkin N, Kusano A, editors. Linking lifetimes: a global view of intergenerational exchange. Lanham, MD: University Press of America; 2002

17. Newman S, Ward C, Smith T, Wilson JO, McCrea JM. Intergenerational programs: past, present, and future. Washington, DC: Taylor \& Francis; 1997.

18. Chowdhary U, Schultz CM, Hasselriis P, Kujath HA, Penn D, Henson S. Intergenerating activities and aging appreciation of elementary school children. Educ Gerontol. 2000;26:541-64.

19. Dunham CC, Casadonte DJ. Children's attitudes and classroom interaction in an intergenerational education program. Educ Gerontol. 2009;35:453-64.

20. Jones ED, Herrick C, York RF. An intergenerational group benefits both emotionally disturbed youth and older adults. Issues Ment Health Nurs. 2004;25:753-67.

21. Newman S, Morris GA, Streetman H. Elder-child interaction analysis. Child Youth Serv. 1999;20:129-45.

22. Fried LP, Carlson MC, Freedman M, Frick KD, Glass TA, Hill J, et al. A social model for health promotion for an aging population: initial evidence on the experience corps model. J Urban Health. 2004;81:64-78.

23. Barron JS, Tan EJ, Yu Q, Song M, McGill S, Fried LP. Potential for intensive volunteering to promote the health of older adults in fair health. J Urban Health. 2009;86:641-53.

24. Carlson MC, Saczynski JS, Rebok GW, Seeman T, Glass TA, McGill S, et al. Exploring the effects of an everyday activity program on executive function and memory in older adults: experience corps. Gerontologist. 2008;48:793-801.

25. Fujiwara $Y$, Sakuma N, Ohba H, Nishi M, Lee S, Watanabe N, et al. REPRINTS: effects of an intergenerational health promotion program for older adults in Japan. J Intergener Relatsh. 2009;7:17-39.

26. Hong SI, Morrow-Howell N. Health outcomes of experience corps: a high-commitment volunteer program. Soc Sci Med. 2010;71:414-20.

27. Murayama Y, Ohba H, Yasunaga M, Nonaka K, Takeuchi R, Nishi M, et al. The effect of intergenerational programs on the mental health of elderly adults. Aging Ment Health. 2015;19:306-14.

28. Sakurai R, Yasunaga M, Murayama Y, Ohba H, Nonaka K, Suzuki H, et al. Long-term effects of an intergenerational program on functional capacity in older adults: results from a seven-year follow-up of the REPRINTS study. Arch Gerontol Geriatr. 2016:64:13-20.

29. Tan EJ, Xue QL, Li T, Carlson MC, Fried LP. Volunteering: a physical activity intervention for older adults - the experience corps program in Baltimore. $J$ Urban Health. 2006;83:954-69.

30. Murayama Y, Ohba H, Yasunaga M, Nonaka K, Takeuchi R, Nishi M, et al. The effect of intergenerational programs in an elementary school on the attitude toward community activities in their junior high school days: a case report of senior volunteers engaged in reading picture book REPRINTS. Jpn J Geriatr. 2012;34:382-93.

31. Rebok GW, Carlson MC, Glass TA, McGill S, Hill J, Wasik BA, et al. Short-term impact of experience corps participation on children and schools: results from a pilot randomized trial. J Urban Health. 2004;81:79-93.

32. Yasunaga M, Murayama Y, Takahashi T, Ohba H, Suzuki H, Nonaka K, et al. Multiple impacts of an intergenerational program in Japan: evidence from the research on productivity through intergenerational sympathy project. Geriatr Gerontol Int. 2016;16:98-109.

33. Bostrom AK. Lifelong learning, intergenerational learning and social capital: from theory to practice. Stockholm: Institute of International Education, Stockholm University; 2003.

34. Bekkers $\mathrm{R}$, Volker B, van der Gaag M, Flap H. Social networks of participants in voluntary associations. In: Lin N, Erikson BCH, editors. Social capital: an international research program. New York: Oxford University Press; 2008. p. 185-205.

35. Fujiwara $Y$, Nishi M, Watanabe $N$, Lee $\mathrm{S}$, Inoue $\mathrm{K}$, Yoshida $\mathrm{H}$, et al. An intergenerational health promotion program involving older adults in urban areas "research of productivity by intergenerational sympathy (REPRINTS)": first-year experience and short-term effects. Nihon Koshu Eisei Zasshi. 2006; 53:702-14.

36. REPRINTS, \& REPRINTS Network. 2017. https://www.nporeprints.com. Accessed 22 Aug 2017.

37. Kawasaki City Hall. 2015. http://www.city.kawasaki.jp/170/page/0000082101. html Accessed 1 Nov 2018.

38. Cabinet Office Japan. Social capital: Toward A virtuous cycle of rich human relationships and civic activities. 2003. https://www.npo-homepage.go.jp/ 
toukei/2009izen-chousa/2009izen-sonota/2002social-capital. Accessed 29 Aug 2017.

39. Fujiwara T, Yamaoka Y, Kawachi I. Neighborhood social capital and infant physical abuse: a population-based study in Japan. Int J Ment Health Syst. 2016;10:13.

40. Novak D, Suzuki E, Kawachi I. Are family, neighborhood and school social capital associated with higher self-rated health among Croatian high school students? A population-based study. BMJ Open. 2015;5:e007184.

41. Hasebe M, Koike T, Fukaya T, Nonaka K, Kobayashi E, Nishi M, et al. Association between the perception of trust in another person and reciprocity, and the health of the elderly living alone [Hitori gurashi koureisya ni okeru tasya heno sinrai to gosyusei ni kansuru kojin no ninshiki to kenkou tono kanren]. J Health Welf Stat. 2015;62:9-16.

42. Roudenbush SW, Bryk AS. Hierarchical linear models: applications and data analysis methods. 2nd ed. SAGE: Newbury Park, CA; 2002.

43. Statistics Bureau, Ministry of Internal Affairs and Communications. 2016. https://www.e-stat.go.jp/stat-search/files?page $=1 \&$ layout=datalist\&toukei $=$ $00200521 \&$ tstat $=000001080615 \&$ cycle $=0 \&$ tclass $1=000001089055 \&$ tclass $2=$ 000001089056\&second2=1. Accessed 1 Nov 2018.

44. Cabinet Office Japan. National survey on lifestyle preferences. 2007. http://warp.da.ndl.go.jp/info:ndljp/pid/10361265/www5.cao.go.jp/seikatsu/ senkoudo/senkoudo.html. Accessed 29 Aug 2017.

45. Fujiwara Y, Watanabe N, Nishi M, Ohba H, Lee S, Kousa Y, et al. Indirect effects of school volunteering by senior citizens on parents through the 'REPRINTS' intergenerational health promotion program. Nihon Koshu Eisei Zasshi. 2010:57:458-66.

46. Kawasaki city. Demographic survey 2015. 2015. http://www.city. kawasaki.jp/170/cmsfiles/contents/0000075/75134/27hokokusyo.pdf. Accessed 29 Aug 2017.

47. Polson EC, Kim YI, Jang SJ, Johnson BR, Smith B. Being prepared and staying connected: Scouting's influence on social capital and community involvement. Soc Sci Q. 2013;94:758-76.

48. Bridger JC, Luloff AE. Building the sustainable community: is social capital the answer? Sociol Inq. 2007;71:458-72.

49. Kaplan MS. Intergenerational programs in schools: consideration of form and function. International Review of Education/ Internationale Zeitschrift $\mathrm{Fr}$ Erziehungswissenschaft/ Revue Inter. 2002:48:305-34

50. Fujiwara Y, Kuraoka M, Hasebe M, Tide S, Murayama Y, Anji M, et al. Can we construct social systems using multigenerational mutual support? Toward establishing "Positive spiral of care" which makes community sustainable. JSIS. 2017;6:3-8.

51. Kuraoka M, Hasebe M, Nonaka K, Murayama Y, Yasunaga M, Minami U, et al. A study of possibilities and requirements for implementation of intergenerational interaction in a multigenerational cyclical society. JSIS. 2017:69-74.

52. Kaplan M, Sanchez M, Hoffman J. Intergenerational pathways to a sustainable society. Switzerland: Springer; 2017.

53. Vojak C, Hopping D, Eheart BK, Power MB. Completing the circle of care: alternative housing at Hope meadows. 2007. http://ghdc.generationsofhope. org/docs NP 1-2_Circle_of_Care.pdf. Accessed 29 Aug 2017.

54. Murayama Y, Takeuchi R, Ohba H, Yasunaga M, Kuraoka M, Nonaka K, et al. Social concern and the present state of intergenerational programs: an analysis of newspaper articles and a survey of organizations. Nihon Koshu Eisei Zasshi. 2013;60:138-45.

Ready to submit your research? Choose BMC and benefit from:

- fast, convenient online submission

- thorough peer review by experienced researchers in your field

- rapid publication on acceptance

- support for research data, including large and complex data types

- gold Open Access which fosters wider collaboration and increased citations

- maximum visibility for your research: over $100 \mathrm{M}$ website views per year

At $\mathrm{BMC}$, research is always in progress.

Learn more biomedcentral.com/submissions 